\title{
Evaluation of blended fertilizer rates for improving production of food barley (Hordeum vulgare L.) in Semen Ari District, Southwestern Ethiopia
}

\author{
M. Malla ${ }^{1 *(\mathbb{D}), G . \text { Tesema }^{1}, \text { S. Tesema }}{ }^{1}$, A. Hegano ${ }^{1}$ and S. Negash ${ }^{2}$ \\ Received 23 July 2021, Revised 18 September 2021, Accepted 20 December 2021, Published online 31 December 2021
}

\begin{abstract}
A B S T R A C T
Depletion of soil fertility, depletion of macro- and micro-nutrients and soil organic matter and inappropriate and imbalanced fertilizer application are among the most important factors that reduces the food barley production in Ethiopia. Therefore, the experiment was conducted to evaluate NPSB blended fertilizer rate effect on improving production of food barley in Semen Ari District, Southwestern Ethiopia during main cropping season. Control, (142 NPS + 159 Urea) kg ha-1, (150 NPSB + 41 Urea) kg ha-1, (200 NPSB + 72 Urea) kg ha-1, (250 NPSB + 102 Urea) $\mathrm{kg} \mathrm{ha}^{-1}$ and (100 NPSB + 161 Urea) $\mathrm{kg} \mathrm{ha}^{-1}$ treatments were used for the experiment which laid out in RCBD following three replication with spacing of $20 \mathrm{~cm}$ between rows; and HB 1307 improved food barley seeds were drilled on prepared rows. Full dose of blended and potassium fertilizers were applied at planting time and urea was applied in two split. The result revealed that food barley responded well to application of N, P, S and $B$ than the unfertilized one. Application of $100 \mathrm{~kg} \mathrm{ha}^{-1}$ NPSB $+161 \mathrm{~kg} \mathrm{ha}^{-1}$ Urea resulted in highest grain yield of $3806.3 \mathrm{~kg} \mathrm{ha}^{-1}$, while the lowest grain yield of $1939.2 \mathrm{~kg} \mathrm{ha}^{-1}$ was recorded from the nil. Moreover, the highest net benefit of $32124.56 \mathrm{ETB} \mathrm{ha}^{-1}$ and economic returns of $942.2 \%$ was recorded in response to application of $100 \mathrm{~kg} \mathrm{ha}^{-1} \mathrm{NPSB}+161 \mathrm{~kg} \mathrm{ha}^{-1}$ Urea. Application of $100 \mathrm{~kg} \mathrm{ha}^{-1} \mathrm{NPSB}+161 \mathrm{~kg} \mathrm{ha}^{-1}$ Urea gave $49.05 \%$ yield increment and $40.24 \%$ increment in economic return over the control. Therefore, we recommend application of $100 \mathrm{~kg} \mathrm{ha}^{-1}$ NPSB $+161 \mathrm{~kg} \mathrm{ha}^{-1}$ Urea for farmers and investor's in study area and similar agro-ecologies as it was optimum for improving food barley production. Further studies and investigation should be done on plant nutrient uptake, nutrient use efficiency and over location.
\end{abstract}

Keywords: Blended fertilizer, Economic return, Productivity, Soil fertility

${ }^{1}$ Southern Agricultural Research Institute, Jinka Agricultural Research Center, P.O. Box 96 Jinka, Ethiopia

${ }^{2}$ Oromia Agricultural Research Institute, Fadis Agricultural Research Center, P.O. Box 904 Harar, Ethiopia

*Corresponding author's email: mmalla658@gmail.com (M. Malla)

Cite this article as: Malla, M., Tesema, G., Tesema, S., Hegano, A. and Negash, S. 2021. Evaluation of blended fertilizer rates for improving production of food barley (Hordeum vulgare L.) in Semen Ari District, Southwestern Ethiopia. Int. J. Agril. Res. Innov. Tech. 11(2): 10-17. https://doi.org/10.3329/ijarit.v11i2.57250

\section{Introduction}

Food barley (Hordeum vulgare L.) is cereal crop belongs to genius Hordeum in the tribe Triticeae of the family Poaceae. It is grown worldwide with greater concentration in temperate areas and high altitudes of the tropics and subtropics. It is one of the most important staple food crops in the highlands of Ethiopia. It has the great importance in social and food habits of Ethiopian people; and used for the preparation of different foodstuffs. The straw is used as animal feed, especially during the dry season. It is also useful for thatching roofs and as bedding (MoANR, 2016). It is the fifth most important cereal crop in Ethiopia and third in South Omo Zone in terms of area of production and productivity (CSA, 2016). Despite its wide range of production, the productivity of barley in the study Zone is low with average yield of $1250 \mathrm{~kg} \mathrm{ha}^{-1}$; which is below the crop potential of $4780 \mathrm{~kg} \mathrm{ha}^{-1}$ and $3540 \mathrm{~kg} \mathrm{ha}^{-}$ ${ }^{1}$ on research station and on farm, respectively for food barley variety HB 1307 (Lakew and Bekele, 2008) and national average yield of $1966 \mathrm{~kg} \mathrm{ha}^{-1}$ (CSA, 2016).

Many constraints hamper agricultural productivity in Ethiopia. Ethiopian soils have been subjected to severe degradation caused by natural and man-made factors (IFDC, 2015). Most of Ethiopian soils, especially in the highlands, are low in nutrient content due to erosion, leaching and absence of nutrient recycling (Zeleke et al., 2010). Yihenew (2002) 
reported that most of the areas used for cereal crops production, especially for barley, teff and wheat are low in soil fertility which hamper the productivity of cereal crops. Soil fertility problems are the main constraints that hinder barley production (Abera et al., 2011). Farmers recognized that much of their farmlands were not used for barley production because of poor soil fertility problem that reduces yield. Additionally, Agegnehu et al. (2011) reported that poor soil fertility particularly nitrogen and phosphorus nutrient deficiency, is one of the main barley production constraints in Ethiopia. Soil fertility depletion is among the most important limiting factor for barley production in the highlands of Ethiopia (Chilot et al., 1998; Woldeyesus and Chilot, 2002; Bayeh and Berhane, 2011). Fertilizer use in Ethiopia has focused mainly on the use and application of nitrogen and phosphorus fertilizers in the form of Urea and DAP respectively only for almost all crops starting since early 1970's. Such unbalanced application of plant nutrients may aggravate the depletion of other important nutrient elements in soils (Fayera et al., 2014). Moreover, soil fertility improvement for enhanced barley production has not covered all the barley growing areas of the country (Getachew et al., 2011).

Balanced fertilization is the key to sustainable crop production and maintenance of soil health and economic consideration, however an imbalanced fertilizer application results in low fertilizer use efficiency which leading to less economic returns and a greater threat to the environment (Abiye et al., 2004). Application of NPSB blended fertilizer with rate of $200 \mathrm{~kg} \mathrm{ha}^{-1}$ for production of food barley gave $70.41 \%$ yield increment and $68.97 \%$ increment in economic return over the absolute control; it gave $22.45 \%$ and 23.29\% yield increment over the recommended NP fertilizer (Melkamu et al., 2019). Moreover, recently acquired soil inventory data revealed that the deficiencies of most of nutrients such as, nitrogen, phosphorus, sulfur, boron and potassium are widespread in soils of study area (ATA, 2016). Even though, appropriate and balanced application of blended fertilizer including micronutrients resulted in optimum yield and economic return of food barley, information on the application of rate of blended fertilizer (NPSB), was not determined for the study area. Therefore, the experiment was designed to evaluate the effects of NPSB blended fertilizer rates on improving production of food barley (Hordeum vulgare L.) in Semen Ari District, Southwestern Ethiopia.

\section{Materials and Methods}

\section{Study area description}

The experiment was conducted in 2018-2019 and 2019-2020 main season at Shamabulket kebele in Semen Ari District, Southwestern Ethiopia. The experimental site was located at latitude of $0^{\circ} 11^{\prime} 35.95$ " N, longitude of $036^{\circ} 39^{\prime} 07.95$ 'E and elevation of 2579 m.a.s.l. The annual average rainfall of Semen Ari District was $1616 \mathrm{~mm}$. The mean minimum monthly temperature ranges between $10.71^{\circ} \mathrm{C}-11.50^{\circ} \mathrm{C}$ and mean maximum monthly temperature ranges between $19.52^{\circ} \mathrm{C}$ $23.36^{\circ} \mathrm{C}$ (Bulki Mender Metro Station). The experimental area has diversity of climate, soil and landforms. The topography of the District includes mountains, hills, uplands and lowland plains. The District generally experiences two cropping seasons namely main cropping (September- February) and the second season was from March to August.

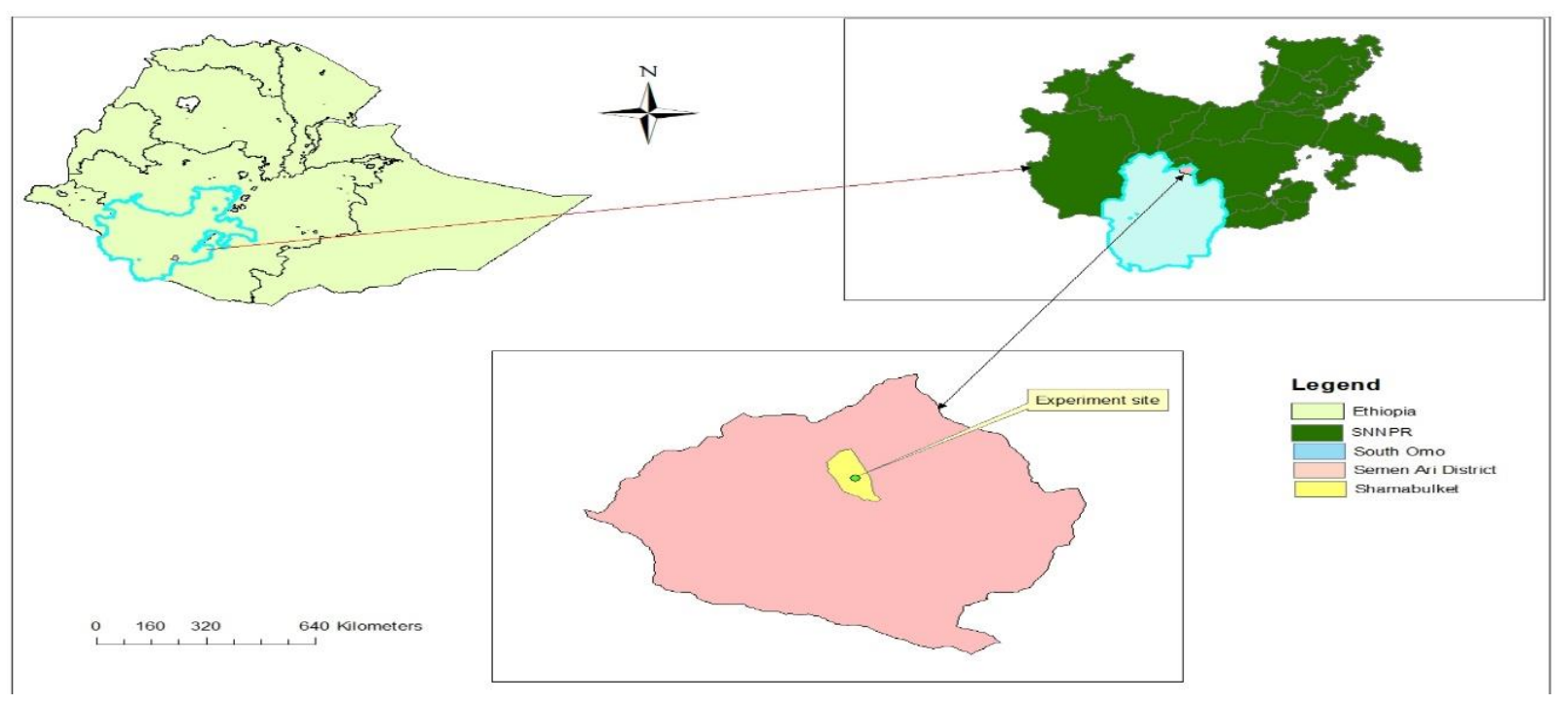

Fig. 1. Map of study area. 


\section{Experimental design and treatments}

The experiment was laid out in Randomized Complete Block Design (RCBD) following three replications. The experimental site was ploughed and harrowed before sowing. The improved food barley variety HB 1307 was used for the experiment. Improved variety HB 1307 was used because of its superior in grain yield performance in most environments with satisfactory grain yield stability, more resistant to scald and leaf rust and comparable for net and spot blotches, better agronomic characteristics, particularly lodging tolerance with good biomass yields and moderate tolerance to water logging and superiority of its physical grain quality (Lakew and Bekele, 2008). Plot size was $3 \mathrm{~m}$ by $4 \mathrm{~m}$. Furrow rows were made manually in spacing of $20 \mathrm{~cm}$ apart and food barley seed was drilled manually and thinned appropriately following management recommendation for barley. The experiment consisting of six treatments as presented in Table 1.

Table 1. Treatment set up of the experiment.

\begin{tabular}{|l|c|c|c|c|}
\hline Fertilizer $\left(\mathrm{kg} \mathrm{ha}^{-1}\right)$ & \multicolumn{4}{|c|}{ Nutrients in $\mathrm{kg} \mathrm{ha}^{-1}$} \\
\hline Control & $\mathrm{N}$ & $\mathrm{P}_{2} \mathrm{O}_{5}$ & $\mathrm{~S}$ & $\mathrm{~B}$ \\
\hline 142 NPS + 159 Urea & $\mathrm{O}$ & $\mathrm{O}$ & $\mathrm{O}$ & $\mathrm{O}$ \\
\hline 150 NPSB+41 Urea & 92 & 54 & 10 & 0 \\
\hline 200 NPSB + 72 Urea & 46 & 54 & 10.1 & 1.07 \\
\hline 250 NPSB + 102 Urea & 69 & 72 & 13 & 1.4 \\
\hline 100 NPSB +161 Urea & 92 & 90 & 17 & 1.7 \\
\hline
\end{tabular}

$100 \mathrm{~kg} \mathrm{ha}^{-1}$ of KCl was applied for all treatments except control or unfertilized treatment.

Urea, TSP and $\mathrm{KCl}$ was used as a source of nitrogen $(\mathrm{N})$, phosphorous $(\mathrm{P})$ and potassium $(\mathrm{K})$, respectively. Full dose of blended fertilizers, potassium and phosphorous fertilizers were applied at planting time and urea was applied in two splits; of which half was applied at planting time and half was top dressed during growth stage. The plots were kept free by hand weeding.

\section{Data collection and analysis}

Treatment effects were determined using plant height, number of tillers per plant, spike length, seed per spike, above ground biomass, thousand kernel weight and grain yield. Composite soil sample was collected before planting in zigzag movement with the sampling depth of $0-20 \mathrm{~cm}$ and analyzed for texture, $\mathrm{pH}$, organic carbon, total nitrogen, available phosphorus, available sulphur and available boron. Analysis of variance was performed using the GLM procedure of SAS Software Version 9.1. Treatment effects were considered significant in all statistical calculations if the P-values were $<0.05$. Means were separated using Least Significant Difference (LSD) test.

\section{Partial budget analysis}

The economic evaluation comprising partial budget analysis with dominance and marginal analysis was carried out. To estimate economic parameters, the grain yield was valued based on average market price collected from the local markets during two consecutive years of production. The average cost of urea, NPS, NPSB and $\mathrm{KCl}$ was $15.25,15.57,15.57$ and 15.46 birr per kilogram, respectively. A wage rate of 50 birr a man per day and 11 birr per kilogram of grain value of barley was considered. The dominance analysis was also done, which was used to select potentially profitable treatments; it was carried out by first listing the treatments in order of increasing costs that vary.

Any treatment that has net benefits that are less than or equal to those of a treatment with lower costs that vary is dominated. The selected treatments by using this technique were referred as un-dominated treatments. For each pair of ranked un-dominated treatments, a percentage marginal rate of return (\% MRR) was calculated. The percent MRR between any pair of undominated treatments denoted the return per unit of investment in crop management practices expressed as percentage. Marginal rate of return (\% MRR) was calculated as the ratio of differences between net benefits of successive treatments to the difference between total variable costs of successive treatments (CIMMYT, 1988). For a treatment to be considered a worthwhile option to farmers, the marginal rate of return (MRR) needed to be at least $100 \%$. Thus, the minimum acceptable rate of return was considered to be $100 \%$. Some of the concepts used in the partial budget analysis are gross field benefit (GFB), total variable cost (TVC) and net benefit (NB).

Gross margin $($ ETB ha-1 $)=$ Total revenue $\left(\right.$ ETB ha-1 $\left.^{-1}\right)-$ Total variable cost $\left(\right.$ ETB ha-1 $\left.^{-1}\right)$.

NR Net return $\left(E^{2} B h^{-1}\right)=$ Gross margin $\left(E^{-1 B} h^{-1}\right)-$ Total fixed cost $\left(E^{2} B h^{-1}\right)$.

Total cost of production $\left(\mathrm{ETB} \mathrm{ha}^{-1}\right)=$ Total variable cost $\left(\mathrm{ETB} \mathrm{ha}^{-1}\right)+$ Total fixed cost $\left(\mathrm{ETB} \mathrm{ha}^{-1}\right)$.

Benefit-cost ratio $=$ Net Return $/$ Total Cost Production (CIMMYT, 1988). 


\section{Results and Discussion}

\section{Soil analysis}

Analysis of soil sample collected before experiment was done at soil laboratory of Jinka Agricultural Research Centre (Table 2). The soil of the experimental site has a proportion of $5 \%$ sand, $41 \%$ silt and $54 \%$ clay; which was classified as sandy clay based on the soil textural triangle. The organic carbon of experimental site was 2.63\% done by Walkeley-Blacky methods (Black, 1965), which was rated as medium (Tekalign et al., 1991). The $\mathrm{pH}$ of the experimental site was 5.02 , which was implied that the soil of experimental site was strongly acidic according to Tekalign et al. (1991) and Murphy (1968).

The soil of experimental site has total nitrogen of $0.133 \%$ by Keljdal digestion and distillation followed by titration method, which showed that the experimental site has moderate level of total nitrogen according to Tekalign et al. (1991) and Murphy (1968). The experimental soil has available phosphorus of $9.25 \mathrm{ppm}$ analysed by Olsen methods which was effective for both alkaline and acidic soil and extracted by $1 \mathrm{M}$ $\mathrm{NaHCO}_{3}$, which was rated as medium according to Olsen et al. (1954).

The soil of experimental site has available sulphur of $6.32 \mathrm{ppm}$ exist in soil in sulphate $\left(\mathrm{SO}_{4}{ }^{2-}-\mathrm{S}\right)$ form which was done by turbidymetric methods of analysis (acidic and non-calcareous soil) and its extractant was calcium chloride dehydrate as sulphate, which showed that the soil has medium level of sulphur according to Marx et al. (1999) and Horneck et al. (2011); and available boron of $1.24 \mathrm{ppm}$ done by dilute $\mathrm{HCl}$ methods in which most effective and efficient, most applicable for acidic, neutral and alkaline soil and more economical than that of hot water methods (only for alkaline soil), which was categorized under high level according to Horneck et al. (2011).

Table 2. Some physical and chemical properties of the soil before the experiment.

\begin{tabular}{|l|c|}
\hline Soil Properties & Composition \\
\hline Sand (\%) & 5.00 \\
\hline Silt (\%) & 41.00 \\
\hline Clay (\%) & 54.00 \\
\hline Textural class & Sandy clay \\
\hline pH $\left(\mathrm{H}_{2} \mathrm{O}\right)(1: 2.5)$ & 5.02 \\
\hline $\mathrm{OC}(\%)$ & 2.63 \\
\hline TN (\%) & 0.13 \\
\hline Available P (ppm) & 9.25 \\
\hline B (ppm) & 1.24 \\
\hline $\mathrm{S}(\mathrm{ppm})$ as $\mathrm{SO}_{4}$ & 6.32 \\
\hline
\end{tabular}

Table 3. Food barley growth, yield and yield components as influenced by NPSB blended fertilizer rate.

\begin{tabular}{|c|c|c|c|c|c|c|c|}
\hline Treatments & $\begin{array}{l}\text { Plant } \\
\text { Height } \\
(\mathrm{cm})\end{array}$ & $\begin{array}{c}\text { Tiller } \\
\text { No./Plant }\end{array}$ & $\begin{array}{l}\text { Spike } \\
\text { Length } \\
(\mathrm{cm})\end{array}$ & $\begin{array}{c}\text { Seed } \\
\text { No./Spike }\end{array}$ & $\begin{array}{l}\text { Biomass } \\
\left(\mathrm{kg} \mathrm{ha}^{-1}\right)\end{array}$ & $\begin{array}{c}\text { Grain } \\
\text { Yield } \\
\left(\mathrm{kg} \mathrm{ha}^{-1}\right)\end{array}$ & TKW (g) \\
\hline Control & $72.50^{b}$ & $1.60^{c}$ & $4.56^{c}$ & $29.77^{\mathrm{c}}$ & $5974.70^{\mathrm{d}}$ & $1939.20^{d}$ & 43.89 \\
\hline $142 \mathrm{~kg} \mathrm{ha}^{-1} \mathrm{NPS}+159 \mathrm{~kg} \mathrm{ha}^{-1}$ Urea & $94.43^{\mathrm{a}}$ & $2.70^{\mathrm{b}}$ & $6.48^{\mathrm{a}}$ & $40.37^{\mathrm{a}}$ & $10740.30^{b}$ & $3479.80^{\mathrm{ab}}$ & 45.24 \\
\hline $150 \mathrm{~kg} \mathrm{ha}^{-1} \mathrm{NPSB}+41 \mathrm{~kg} \mathrm{ha}^{-1}$ Urea & $92.33^{\mathrm{a}}$ & $2.97^{\mathrm{ab}}$ & $5.65^{b}$ & $35.07^{\mathrm{b}}$ & $8709.10^{c}$ & $2699.50^{c}$ & 48.44 \\
\hline $200 \mathrm{~kg} \mathrm{ha}^{-1} \mathrm{NPSB}+72 \mathrm{~kg} \mathrm{ha}^{-1}$ Urea & $94.20^{\mathrm{a}}$ & $3.00^{\mathrm{ab}}$ & $6.03^{\mathrm{ab}}$ & $34.70^{\mathrm{b}}$ & $9657.70^{b c}$ & $3042.30^{\mathrm{bc}}$ & $47 \cdot 58$ \\
\hline $250 \mathrm{~kg} \mathrm{ha}^{-1} \mathrm{NPSB}+102 \mathrm{~kg} \mathrm{ha}^{-1}$ Urea & $96.47^{\mathrm{a}}$ & $3.00^{\mathrm{ab}}$ & $6.15^{\mathrm{ab}}$ & $38.33^{\mathrm{ab}}$ & $9780.50^{b c}$ & $3234.60^{\mathrm{abc}}$ & 47.55 \\
\hline $100 \mathrm{~kg} \mathrm{ha}^{-1}$ NPSB + $161 \mathrm{~kg} \mathrm{ha}^{-1}$ Urea & $95.10^{\mathrm{a}}$ & $3.60^{\mathrm{a}}$ & $6.78^{\mathrm{a}}$ & $38.23^{\mathrm{ab}}$ & $12497.80^{\mathrm{a}}$ & $3806.30^{\mathrm{a}}$ & 44.10 \\
\hline $\mathrm{LSD}_{0.05}$ & 4.43 & 0.89 & 0.81 & 4.59 & 1747.80 & 672.82 & NS \\
\hline CV (\%) & 2.69 & 17.47 & 7.53 & 6.99 & 10.05 & 12.19 & 7.10 \\
\hline
\end{tabular}

Means with the same letter within column shows statistically not significant different at $L S D_{0.05}$

No. $=$ Number $; T K W=$ Thousand Kernel Weight CV $=$ Coefficient of Variation

Food barley growth, yield and yield components have influenced by NPSB blended fertilizer rate. Plant height, tiller number per plant, spike length, number of seed per spike, above ground biomass and grain yield were influenced by NPSB blended fertilizer rate, whereas thousand kernel weight did not affected by NPSB blended fertilizer rate.

\section{Plant height}

The highest plant height of $96.47 \mathrm{~cm}$ was recorded from $250 \mathrm{~kg} \mathrm{ha}^{-1} \mathrm{NPSB}+102 \mathrm{~kg} \mathrm{ha}^{-1}$ Urea followed by $100 \mathrm{~kg} \mathrm{ha}^{-1} \mathrm{NPSB}+161 \mathrm{~kg} \mathrm{ha}^{-1}$ Urea which was in statistical parity with the rest treatment except unfertilized one, while the lowest height of $72.50 \mathrm{~cm}$ was recorded from the absolute control treatment. This result was in line of agreement with application of different 
blended fertilizers had significant influence on plant height of barley with increasing blended fertilizers application rates (Melkamu et al., 2019; Abdisa, 2020); and also macro- and micronutrients (Nitrogen, Phosphorous with Sulfur and Boron) fertilizers application can increase plant height with increasing doses and combination (Dewal and Pareek, 2004; Gupta et al., 2004; Arif et al., 2006; Bereket et al., 2014).

\section{Tiller number per plant}

Number of tiller per plant was affected by NPSB blended fertilizer rate of which the largest tiller number of 3.60 was recorded from $100 \mathrm{~kg} \mathrm{ha}^{-1}$ NPSB + $161 \mathrm{~kg} \mathrm{ha}^{-1}$ Urea which was in statistical parity with all treatments rather than $142 \mathrm{~kg} \mathrm{ha}^{-1}$ NPS + $159 \mathrm{~kg} \mathrm{ha}^{-1}$ Urea and absolute control treatments, while the smallest tiller number of 1.60 was recorded from nil one. In agreement with this result, Abdisa (2020) reported that increase in the numbers of total tillers in response to increasing the rate of NPSB blended fertilizer which may indicate that the importance of availability of balanced nutrients for better growth and development of the plant; and also agree with tiller number per plant was increased significantly across the increased rates of NPS fertilizer (Yared et al., 2020).

\section{Spike length}

The result has revealed that NPSB blended fertilizer rate affects spike length of food barley of which the longest spike length of $6.78 \mathrm{~cm}$ was recorded from $100 \mathrm{~kg} \mathrm{ha}^{-1}$ NPSB $+161 \mathrm{~kg} \mathrm{ha}^{-1}$ Urea which was in statistical parity with the rest of treatments except $150 \mathrm{~kg} \mathrm{ha}^{-1} \mathrm{NPSB}+41 \mathrm{~kg} \mathrm{ha}^{-1}$ Urea and absolute control treatments, while the shortest spike length of $4.56 \mathrm{~cm}$ was recorded from the nil one. The result was in agreement with the highest spike length was recorded at highest application rates of blended fertilizer on food barley (Melkamu et al., 2019); and nitrogen and phosphors fertilizer increases spike length, number of seeds per spike, number of fertile tillers, non-fertile tillers and grain yield of barley, especially at higher doses (Wakene et al., 2014; Mesfin and Zemach, 2015).

\section{Number of kernels per spike}

Number of seed per spike was significantly influenced by NPSB blended fertilizer rate of which the largest number of seed per spike of 40.37 was recorded from $142 \mathrm{~kg} \mathrm{ha}^{-1} \mathrm{NPS}+159 \mathrm{~kg}$ $\mathrm{ha}^{-1}$ Urea which was in statistical parity with 250 $\mathrm{kg} \mathrm{ha}^{-1}$ NPSB $+102 \mathrm{~kg} \mathrm{ha}^{-1}$ Urea and $100 \mathrm{~kg} \mathrm{ha}^{-1}$ NPSB + $161 \mathrm{~kg} \mathrm{ha}^{-1}$ Urea treatments, whereas the lowest number of seed per spike of 29.77 was recorded from the unfertilized treatment. The result was agree with NPSB blended fertilizer enhances number of kernels per spike which might be due to the fact that phosphorous level increment is essential in development of grains (Abdisa, 2020) and increment of number of kernel with the application blended fertilizer (Abebe, 2018). This may be due to the reason that Boron plays a vital role in grain setting and helps in grain filling and ultimately sterility is reduced and number of grains per spike increased (Tahir et al., 2009; Mitra and Jana, 1991).

\section{Biomass}

Analysis of Variance revealed that above ground biomass of food barley has significantly influenced by NPSB blended fertilizer rate of which the highest above ground biomass of $12497.80 \mathrm{~kg} \mathrm{ha}^{-1}$ was obtained from application of $100 \mathrm{~kg} \mathrm{ha}^{-1}$ NPSB $+161 \mathrm{~kg} \mathrm{ha}^{-1}$ Urea followed by $142 \mathrm{~kg} \mathrm{ha}^{-1} \mathrm{NPS}+159 \mathrm{~kg} \mathrm{ha}^{-1}$ Urea treatment with biomass of $10740.30 \mathrm{~kg} \mathrm{ha}^{-1}$, while the lowest above ground biomass of $5974.70 \mathrm{~kg} \mathrm{ha}^{-1}$ was recorded from the unfertilized treatment. The result was agree with blended fertilizer supply had a marked effect on the above ground biomass, grain yield and straw yield of which the maximum above ground biomass $\left(12.63 \mathrm{t} \mathrm{ha}^{-1}\right)$ was obtained from $200 \mathrm{~kg} \mathrm{ha}^{-1}$ NPSB of blended fertilizer application (Melkamu et al., 2019). Likewise, blended fertilizer application increases above ground biomass in $20.17 \%$ over the control with recommended NP fertilizer (Abebe, 2018) and nitrogen increases vegetative growth of plants, especially at higher doses and contributed for the significant increase in total biomass (Wakene et al., 2014).

\section{Grain yield}

Grain yield of food barley has significantly influenced by NPSB blended fertilizer rate of which the highest grain yield of $3806.30 \mathrm{~kg} \mathrm{ha}^{-1}$ was recorded from $100 \mathrm{~kg} \mathrm{ha}^{-1}$ NPSB $+161 \mathrm{~kg} \mathrm{ha}^{-1}$ Urea which was in statistical parity with application of $142 \mathrm{~kg} \mathrm{ha}^{-1} \mathrm{NPS}+159 \mathrm{~kg} \mathrm{ha}^{-1}$ Urea and $250 \mathrm{~kg} \mathrm{ha} \mathrm{hPSB}^{-1} \mathrm{NPS} \mathrm{kg} \mathrm{ha}^{-1}$ Urea treatments, while the lowest grain yield of $1939.20 \mathrm{~kg} \mathrm{ha}^{-1}$ was recorded from unfertilized treatment. Similarly, grain yield of wheat significantly increased due to increasing of nitrogen fertilization (Bereket et al., 2014); application of NPSB blended fertilizer in $200 \mathrm{~kg}$ $\mathrm{ha}^{-1}$ NPSB increases the grain yield of barley in 70.40\% over absolute control (Melkamu et al., 2019); The yield obtained from variety EH 1493 with $200 \mathrm{~kg} \mathrm{ha}^{-1}$ NPSB gave $22.40 \%$ grain yield increment over recommended NP fertilizer application and $48 \%$ yield increment over control treatment due to the synergistic effect of the four nutrients might contributed for improved root growth and increased nutrient use efficiency, thus improved yield components and yield (Abdisa, 2020); and also compared to the control 
(with recommended NP fertilizers), the grain yield were increased by $26.90 \%$ with the application of blended fertilizer $\mathrm{NPS}_{3} \mathrm{~B}_{3} \mathrm{~K}_{3}$ (Abebe, 2018).

\section{Thousand kernel weight}

Analysis of Variance revealed that NPSB blended fertilizer rate did not significantly affects thousand kernel weight of food barley. The result was in line of agreement with different blended fertilizer rates on malt barley has shown no significant influence on thousand kernel weight (Kedir and Ashenafi, 2020); and the interaction blended fertilizer with variety did not significantly affects thousand kernel weight of barley (Fisseha et al., 2020).

\section{Economic analysis}

Partial budget analysis of blended fertilizer rate effect on food barley experiment in Semen Ari District was revealed that the highest net return (28721.81 ETB ha $^{-1}$ ) was obtained in response to application of $100 \mathrm{~kg} \mathrm{ha}^{-1} \mathrm{NPSB}+161 \mathrm{~kg} \mathrm{ha}^{-1}$ Urea which showed $33.16 \%$ higher net return over the nil one (19198.08 ETB ha-1); followed by $142 \mathrm{~kg}$ $\mathrm{ha}^{-1} \mathrm{NPS}+159 \mathrm{~kg} \mathrm{ha}^{-1}$ Urea treatment with net return of $24866.12 \mathrm{ETB} \mathrm{ha}^{-1}$. The lowest net return (19198.08 ETBha $^{-1}$ ) was obtained from unfertilized treatment (nil treatment) (Table 4).

Table 4. Partial budget analysis, effect of NPSB blended fertilizer rate on barley production experiment.

\begin{tabular}{|c|c|c|c|c|c|}
\hline Treatments & $\begin{array}{l}\text { Ave. Yield } \\
\left(\mathrm{kg} \mathrm{ha}^{-1}\right)\end{array}$ & $\begin{array}{l}\text { 10\% Adj. } \\
\text { Yield kg ha }\end{array}$ & $\begin{array}{l}\text { Total Revenue } \\
\text { (TR) in ETB ha }\end{array}$ & $\begin{array}{c}\text { Total Variable } \\
\text { Cost (TVC) in ETB } \\
\text { ha }^{-1}\end{array}$ & $\begin{array}{l}\text { Net Benefit } \\
\left(\text { ETB ha }^{-1}\right)\end{array}$ \\
\hline Control & 1939.2 & 1745.28 & 19198.08 & O & 19198.08 \\
\hline $142 \mathrm{~kg} \mathrm{ha}^{-1} \mathrm{NPS}+159 \mathrm{~kg} \mathrm{ha}^{-1}$ Urea & 3479.8 & 3131.82 & 34450.02 & 6181.15 & 28268.87 \\
\hline $150 \mathrm{~kg} \mathrm{ha}^{-1} \mathrm{NPSB}+41 \mathrm{~kg} \mathrm{ha}^{-1}$ Urea & 2699.5 & $2429 \cdot 55$ & 26725.05 & 4506.45 & 22218.60 \\
\hline $200 \mathrm{~kg} \mathrm{ha}^{-1} \mathrm{NPSB}+72 \mathrm{~kg} \mathrm{ha}^{-1}$ Urea & 3042.3 & 2738.07 & 30118.77 & $5757 \cdot 50$ & 24361.27 \\
\hline $250 \mathrm{~kg} \mathrm{ha}^{-1} \mathrm{NPSB}+102 \mathrm{~kg} \mathrm{ha}^{-1}$ Urea & 3234.6 & 2911.14 & 32022.54 & $6993 \cdot 32$ & 25029.22 \\
\hline $100 \mathrm{~kg} \mathrm{ha}^{-1} \mathrm{NPSB}+161 \mathrm{~kg} \mathrm{ha}^{-1}$ Urea & 3806.3 & 3425.67 & 37682.37 & 5557.81 & 32124.56 \\
\hline
\end{tabular}

10\% Adj. Yield= Grain Yield Adjusted to 10\% downward; TVC= Total Variable Cost; ETB= Ethiopian Birr.

Dominance analysis revealed that among treatments only treatment, which receives $100 \mathrm{~kg}$ $\mathrm{ha}^{-1}$ NPSB $+161 \mathrm{~kg} \mathrm{ha}^{-1}$ Urea and $150 \mathrm{~kg} \mathrm{ha}^{-1}$ NPSB $+41 \mathrm{~kg} \mathrm{ha}^{-1}$ Urea were un-dominated. This indicated that increase in the total cost of these treatments increases the net benefit proportionally; which implies benefits were greater than the lower total costs. The highest net benefit was obtained from the application of 100 $\mathrm{kg} \mathrm{ha-1}$ NPSB + $161 \mathrm{~kg} \mathrm{ha}^{-1}$ Urea with highest marginal rate of return of $942.2 \%$ (Table 5). Therefore, $100 \mathrm{~kg} \mathrm{ha}^{-1}$ NPSB $+161 \mathrm{~kg} \mathrm{ha}^{-1}$ Urea with MRR of $942.2 \%$ was accepted according to CIMMYT (1988) as MRR (\%) was above $100 \%$.

Table 5. Dominance and Marginal (MRR) Analysis.

\begin{tabular}{|c|c|c|c|c|c|}
\hline \multirow[t]{2}{*}{ Treatments } & \multirow{2}{*}{$\begin{array}{l}\text { 10\% Adj. } \\
\text { Yield kg ha-1 }\end{array}$} & \multicolumn{4}{|c|}{ Variables } \\
\hline & & $\begin{array}{c}\text { TVC } \\
\left(\mathrm{ETB} \mathrm{ha}^{-1}\right)\end{array}$ & $\begin{array}{c}\text { Net Benefit } \\
(\text { ETB ha-1) }\end{array}$ & $\begin{array}{c}\text { Dominance } \\
\text { Analysis }\end{array}$ & MRR (\%) \\
\hline Control & 1745.28 & $\mathrm{O}$ & 19198.08 & - & - \\
\hline $150 \mathrm{~kg} \mathrm{ha}^{-1} \mathrm{NPSB}+41 \mathrm{~kg} \mathrm{ha}^{-1}$ Urea & 2429.55 & 4506.45 & 22218.60 & ND & 67.03 \\
\hline $100 \mathrm{~kg} \mathrm{ha}^{-1} \mathrm{NPSB}+161 \mathrm{~kg} \mathrm{ha}^{-1}$ Urea & 3425.67 & 5557.81 & 32124.56 & ND & 942.20 \\
\hline $200 \mathrm{~kg} \mathrm{ha}^{-1} \mathrm{NPSB}+72 \mathrm{~kg} \mathrm{ha}^{-1}$ Urea & 2738.07 & 5757.50 & 24361.27 & $\mathrm{D}$ & - \\
\hline $142 \mathrm{~kg} \mathrm{ha}^{-1} \mathrm{NPS}+159 \mathrm{~kg} \mathrm{ha}^{-1}$ Urea & 3131.82 & 6181.15 & 28268.87 & $\mathrm{D}$ & - \\
\hline $250 \mathrm{~kg} \mathrm{ha}^{-1} \mathrm{NPSB}+102 \mathrm{~kg} \mathrm{ha}^{-1}$ Urea & 2911.14 & $6993 \cdot 32$ & 25029.22 & $\mathrm{D}$ & - \\
\hline
\end{tabular}

$D=$ Dominated $; D=$ Non-Dominated MRR $(\%)=$ Marginal Rate of Return in percent .

\section{Conclusion and Recommendation}

Depleting of soil fertility, inappropriate and imbalanced fertilizer application including different blended fertilizer are among the most important factors that reduces the productivity of cereal crops including food barley in the study area specifically and in region as compared to the crop potential and average yield of other African countries. Therefore, the experiment was carried out to evaluate the effect of different blended fertilizer rates on improving the production of food barley in Semen Ari District, Southwestern
Ethiopia. The finding of this experiment has revealed that food barley responded well to the application of $\mathrm{N}, \mathrm{P}, \mathrm{K}, \mathrm{B}$ and $\mathrm{S}$ than the nil one. Plant height, tiller number per plant, spike length, number of seed per spike, above ground biomass and grain yield were influenced by NPSB blended fertilizer rate, whereas thousand kernel weight did not affected by NPSB blended fertilizer rate. Application of $100 \mathrm{~kg} \mathrm{ha}^{-1} \mathrm{NPSB}+161 \mathrm{~kg} \mathrm{ha}^{-1}$ Urea resulted in highest grain yield, while the lowest grain yield was recorded from the nil. Moreover, based on partial budget analysis, also the highest net benefits of $32124.56 \mathrm{ETB} \mathrm{ha}^{-1}$ and economic 
returns/marginal rate of return of $942.2 \%$ was recorded in response to application of $100 \mathrm{~kg} \mathrm{ha}^{-1}$ NPSB $+161 \mathrm{~kg} \mathrm{ha}^{-1}$ Urea. Application of $100 \mathrm{~kg} \mathrm{ha}^{-}$ 1 NPSB + $161 \mathrm{~kg} \mathrm{ha}^{-1}$ Urea gives $49.05 \%$ yield increment and $40.24 \%$ increment in economic return over the control. Therefore, we recommend application of $100 \mathrm{~kg} \mathrm{ha}^{-1} \mathrm{NPSB}+161 \mathrm{~kg} \mathrm{ha}^{-1}$ Urea for farmers and investor's in study area and similar agro-ecologies as it was optimum for improving food barley productivity. Further studies and investigation should be done on plant nutrient uptake, nutrient use efficiency and over location.

\section{Conflict of interest}

The authors declare that there is no conflict of interest regarding the publication of this article.

\section{Acknowledgements}

The authors acknowledge Southern Agricultural Research Institute and Agricultural Growth Program for financial support to conduct the experiment and Jinka Agricultural Research Center for its strong administrative facilitation by providing important inputs to handle the research accordingly. The collaboration of researchers in the Natural Resource Research Directorate was highly appreciated.

\section{References}

Abdisa, M.K.A. 2020. Effect of blended NPSB fertilizer rates on yield, yield components and quality parameters of food barley (Hordeum vulgare L.) varieties in Walmera District, Central Highland of Ethiopia. MSc Thesis, Ambo University, Ethiopia. pp. 4254.

Abebe, A. 2018. Effects of blended fertilizer rates on growth, yield and quality of malt barley (Hordeum distichum L.) varieties at DebreBerhan district central high land of Ethiopia. MSc Thesis, Haramaya University, Ethiopia. pp. 24-32.

Abera, T., Molla, A., Feyissa, A., Liben, M., Woyema, A., Admassu, L. and Bekele, A. 2011. Research achievements in barley cultural practices in Ethiopia. Barley Research and Development in Ethiopia. 113p.

Abiye, A., Tekalign, M., Peden, D. and Diedhiou, M. 2004. Participatory on-farm conservation tillage trial in the Ethiopian highland Vertisols: The impact of potassium application on crop yields. Expt. Agric. 40(3): 369-379.

https://doi.org/10.1017/Soo14479704002029

Agegnehu, G., Liben, M., Molla, A., Feyissa, A., Bekele, A. and Getaneh, F. 2011. Research achievements in soil fertility management in relation to barley in Ethiopia. Barley Research and Development in Ethiopia. $137 \mathrm{p}$.
Arif, M., Ali, S., Khan, A., Jan, T. and Akbar, M. 2006. Influence of farmyard manure application on various wheat cultivars. Sarhad J. Agric. 22(1): 27.

ATA. 2016. Soil Fertility Status and Fertilizer Recommendation Atlas of the Southern Nations Nationalities and Peoples' Regional State, Ethiopia, by MoANR and Agricultural Transformation Agency (ATA), Addis Ababa, Ethiopia. pp. 144-159.

Bayeh, M. and Berhane, L. 2011. Research achievements in barley cultural practices in Ethiopia. In: Mulatu, B. and Grando, S. (eds). Barley Research and Development in Ethiopia, Proceedings of the $2^{\text {nd }}$ National Barley Research and Development Review Workshop. 28-30 November 2006, HARC, Holetta, Ethiopia. pp. 1-16.

Bereket, H., Dawit, H., Mehretab, H. and Gebremedhin, G. 2014. Effects of mineral nitrogen and phosphorus fertilizers on yield and nutrient utilization of bread wheat on the sandy soils of Hawzen District, Northern Ethiopia. Agric. Fores. Fish. 3(3): 189-198.

Black, C.A. 1965. Methods of soil analysis: physical and mineralogical properties, including statistics of measurement and sampling. Part 2. Chemical and microbiological properties. Agron. 9: 13871388. https://doi.org/10.2134/agronmonogr9.1

CSA. 2016. Agricultural Sample Survey 20152016. Report on Area and Production of Major Crops (Private Peasant Holdings, Meher Season). Statistical Bulletin No. 584. Central Statistics Authority Addis Ababa, Ethiopia. 74p.

Chilot, Y., Fekadu, A. and Woldeyesus, S. 1998. Barley Based Farming Systems in the highlands of Ethiopia. Ethiopian Agricultural Research Organization. Addis Ababa, Ethiopia. 117p.

CIMMYT. 1988. From Agronomic Data to Farmer Recommendations: An Economics Training Manual (No. 27). Economics Program International Maize and Wheat Improvement Center, Mexico, D.F. pp. 13-54.

Dewal, G. S. and Pareek R. G. 2004. Effect of phosphorus, sulphur, and zinc on growth, yield and nutrient uptake of wheat (Triticum aestivum L.). Ind. J. Agro. 49(3): 160-162.

Fayera, A., Mohammed, M. and Adugna, D. 2014. Effects of different rates of NPK and blended fertilizers on nutrient uptake and use efficiency of teff [Eragrostis tef (Zuccagni) Trotter] in Dedessa District, southwestern Ethiopia. J. Biol. Agric. Healthcare. 4(25): 254-258. 
Fisseha, H., Bereket, H., Hintsa, L., Sofonyas, D., Abbadi, G. and Mitiku, H. (eds.). 2020. In: proceeding of national workshop: The Role of Blended Fertilizers in Enhancing Productivity and Quality of Crops in Ethiopia, 07-08 June 2019. Tigray Agricultural Research Institute and Agricultural Growth Program-II, Mekelle, Ethiopia. pp. 156-176.

Getachew, A., Minale, L., Adamu, M., Abraham, F., Agdew, B. and Fite, G. 2011. Research achievements in soil fertility management in relation to barley in Ethiopia. Barley Research and Development in Ethiopia. $137 \mathrm{p}$.

Gupta, V.K., Kumar, S. and Singh, A.K. 2004. Yield and quality of wheat (Triticum aestivum L.) as influenced by sulphur nutrition and weed management. Indian $J$. Agril. Sci. 74(5): 254-256.

Horneck, D.A., Sullivan, D.M., Owen, J.S. and Hart, J.M. 2011. Soil test interpretation guide. Oregon State University Extension Service, U.S. Department of Agriculture. pp. $3-5$.

IFDC. 2015. Assessment of Fertilizer Consumption and Use by Crop in Ethiopia. FUBC Ethiopian Final Report 2015. pp. 9-16.

Kedir, J. and Ashenafi, T. 2020. Growth and yield response of malt barley (Hordeum vulgare L.) to NPSB and nitrogen fertilizers application in Southern Ethiopia. Int. J. Res. Agric. Fores. 7(8): 08-19.

Lakew, B. and Bekele, B. 2008. Registration of Food Barley (Hordeum vulgare L.) Variety HB 1307 for Mid and High Altitude Areas of Ethiopia. East Afr. J. Sci. 2(2): 192-194. https://doi.org/10.4314/eajsci.v2i2.40383

Marx, E.S., Hart, J. and Stevens, R.G. 1999. Soil Test Interpretation Guide. Oregon State University. Soil Sci. 120: 1120-1322.

Melkamu, H.S., Gashaw, M. and Wassie, H. 2019. Effects of different blended fertilizers on yield and yield components of food barley (Hordeum vulgare L.) on Nitisols at Hulla District, Southern Ethiopia. Acad. Res. J. Agri. Sci. Res. 7(1): 49-56.

Mesfin, K. and Zemach, S. 2015. Effect of nitrogen and phosphorus fertilizer rates on yield and yield components of barley (Hordeum vugarae L.) varieties at Damot Gale District, Wolaita Zone, Ethiopia. American J. Agric. Fores. 3(6): 271-275.

https://doi.org/10.11648/j.ajaf.20150306.15

MoANR. 2016. Plant Variety Release, Protection and Seed Quality Control Directorate. Crop Variety Registration ISSUE No. 19. Ministry of Agriculture and Natural Resources, Addis Ababa, Ethiopia. pp. 70-79.
Mitra, A.K. and Jana, P.K. 1991. Effect of doses and method of boron application on wheat in acid Terai soils of North Bengal. Indian $J$. Agron. 36(1): 72-74.

Murphy, H.F. 1968. A report on the fertility status and other data on some soils of Ethiopia. Experimental Station Bulletin No. 44. Collage of Agriculture HSIU. 551p.

Olsen, S.R., Cole, C.V., Watanabe, F.S. and Dean, L.A. 1954. Estimation of available phosphorus in soils by extraction with sodium bicarbonate. USDA Circular 939. pp. 1-19.

Tahir, M., Tanveer, A., Shah, T.H., Fiaz, N. and Wasaya, A. 2009. Yield response of wheat (Triticum aestivum L.) to boron application at different growth stages. Pak. J. Life Soc. Sci. 7(1): 39-42.

Tekalign, T., Haque, I. and Aduayi, E.A. 1991. Soil, plant, water, fertilizer, animal manure \& compost analysis manual. Working Document No. 13. International Livestock Research Center for Africa, Addis Ababa.

Tolera, A., Adamu, M., Abraham, F., Minale, L., Abdo, W., Legesse, A. and Agdew, B. 2011. Research achievements in barley cultural practices in Ethiopia. Barley Research and Development in Ethiopia. 113p.

Wakene, T., Walelign, W. and Wassie, H. 2014. Effects of nitrogen and phosphorus fertilizer levels on growth and development of barley (Hordeum vulgare L.) at Bore District, southern Oromia, Ethiopia. American J. Life Sci. 2(5): 260-266.

https://doi.org/10.11648/j.ajls.20140205.12

Woldeyesus, S. and Chilot, Y. 2002. Participatory client-orientation of research in low-input cropping systems of Ethiopia: a viewpoint. Holetta Agricultural Research Centre, Holetta, Ethiopia. pp. 27-43.

Yared, T., Seyoum, A., Kabna, A., Girma, T. and Obsa, C. 2020. Effect of blended NPS fertilizer levels and row spacing on yield components and yield of food barley (Hordeum vulgare L.) at highland of Guji Zone, Southern Ethiopia. Acad. Res. J. Agril. Sci. Res. 8(6): 609-618.

Yihenew, G. 2002. Selected chemical and physical characteristics of soil of Adet research center and its testing sites in North-western Ethiopia. Eth. J. Nat. Res. 4(2): 199-215.

Zeleke, G., Agegnehu, G., Abera, D. and Rashid, S. 2010. Fertilizer and soil fertility potential in Ethiopia: Constraints and opportunities for enhancing the system. Gates Open Res. 3: 482. https://doi.org/10.21955/gatesopenres.1115635.1 